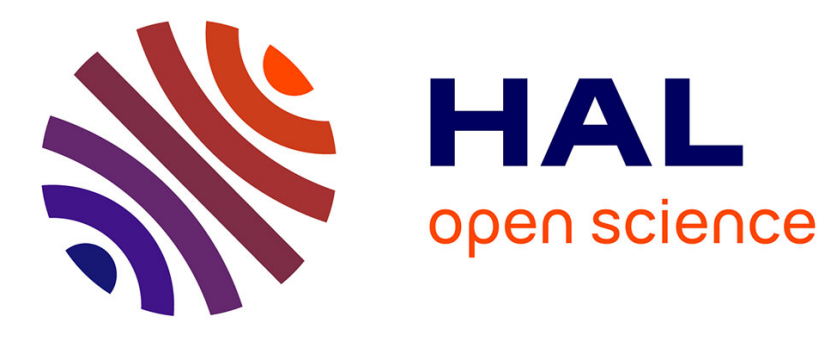

\title{
From Specific $\gamma$-CD/[Nb 6 Cl 12 (H 2 O) 6 ] 2+ Recognition to Biological Activity Tuning
}

\author{
Anton Ivanov, Tatiana Pozmogova, Anastasiya Solovieva, Tatiana Frolova, \\ Olga Sinitsyna, Olga Lundovskaya, Alphiya Tsygankova, Mohamed Haouas, \\ David Landy, Enrico Benassi, et al.
}

\section{To cite this version:}

Anton Ivanov, Tatiana Pozmogova, Anastasiya Solovieva, Tatiana Frolova, Olga Sinitsyna, et al.. From Specific $\gamma$-CD/[Nb 6 Cl 12 (H 2 O) 6 ] 2+ Recognition to Biological Activity Tuning. Chemistry - A European Journal, 2020, 26 (33), pp.7479-7485. 10.1002/chem.202000739 . hal-03000995

\section{HAL Id: hal-03000995 https://hal.science/hal-03000995}

Submitted on 12 Nov 2020

HAL is a multi-disciplinary open access archive for the deposit and dissemination of scientific research documents, whether they are published or not. The documents may come from teaching and research institutions in France or abroad, or from public or private research centers.
L'archive ouverte pluridisciplinaire HAL, est destinée au dépôt et à la diffusion de documents scientifiques de niveau recherche, publiés ou non, émanant des établissements d'enseignement et de recherche français ou étrangers, des laboratoires publics ou privés. 


\title{
From specific $\mathrm{Y}-\mathrm{CD} /\left[\mathrm{Nb}_{6} \mathrm{Cl}_{12}\left(\mathrm{H}_{2} \mathrm{O}\right)_{6}\right]^{2+}$ recognition to biological activity tuning
}

\author{
Anton A. Ivanov ${ }^{[\mathrm{a}]}$, Tatiana N. Pozmogova ${ }^{[\mathrm{b}, \mathrm{c}]}$, Anastasiya O. Solovieva ${ }^{[\mathrm{c}, \mathrm{d}]}$, Tatiana S. Frolova ${ }^{[\mathrm{b}, \mathrm{d}, \mathrm{e}]}$, \\ Olga I. Sinitsyna $a^{[b, e]}$, Olga V. Lundovskaya ${ }^{[a]}$, Alphiya R. Tsygankova ${ }^{[a, b]}$, Mohamed Haouas ${ }^{[f]}$, \\ David Landy ${ }^{[g]}$, Enrico Benassi ${ }^{[\mathrm{b}, \mathrm{h}]}$, Lidiya V. Shestopalova ${ }^{[\mathrm{b}]}$, Clément Falaise ${ }^{[f]}$, Emmanuel Cadot ${ }^{[f]}$, \\ Michael A. Shestopalov ${ }^{[a]}$, Pavel A. Abramov ${ }^{*[a, j]}$, Maxim N. Sokolov ${ }^{[a, b]}$
}

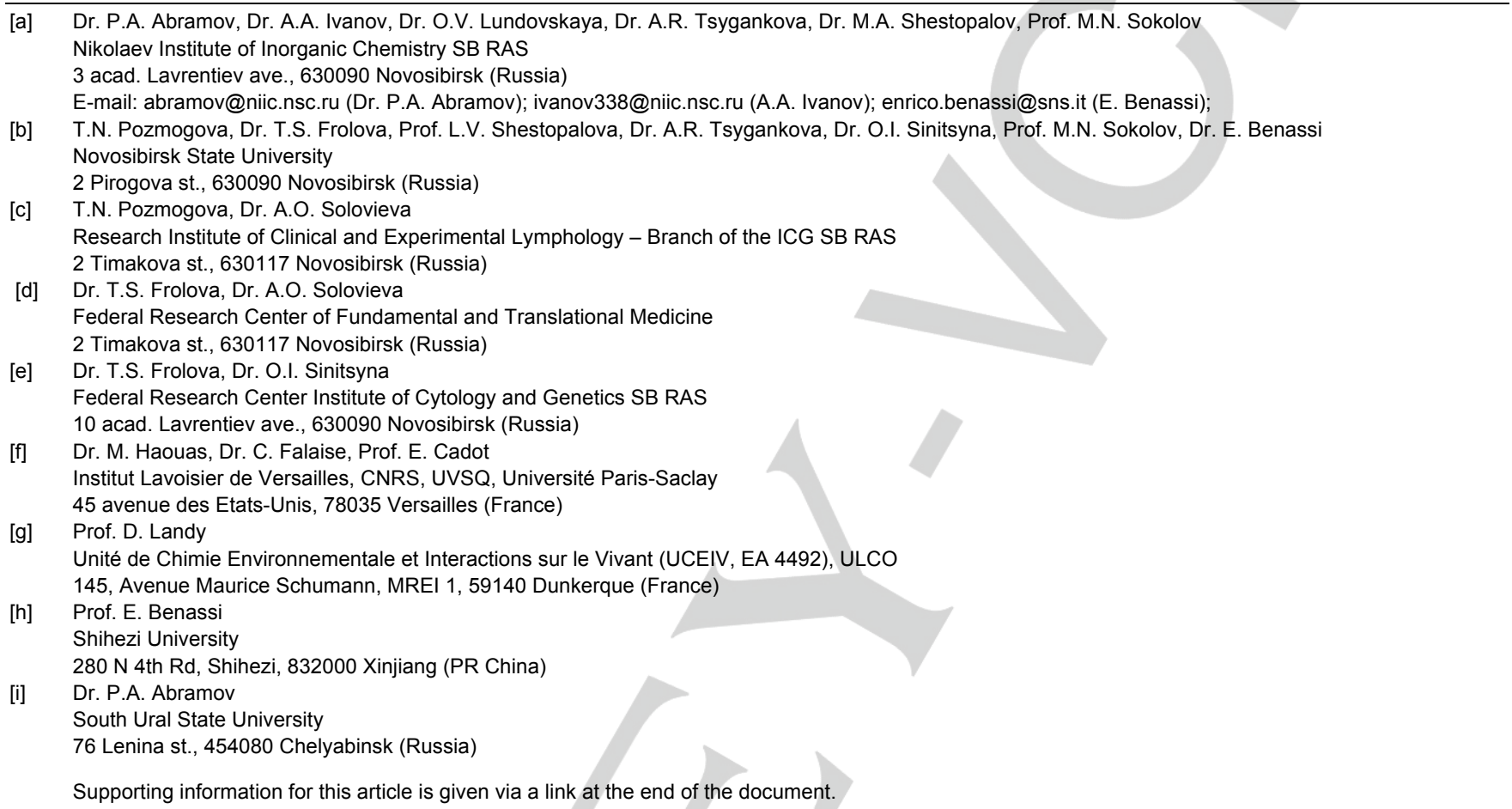

\begin{abstract}
Specific molecular recognition of $\mathrm{y}$-cyclodextrin $(\mathrm{Y}-\mathrm{CD})$ toward cationic hexanuclear niobium $\left[\mathrm{Nb}_{6} \mathrm{Cl}_{12}\left(\mathrm{H}_{2} \mathrm{O}\right)_{6}\right]^{2+}$ cluster complex in aqueous solutions results in a 1:1 supramolecular assembly $\left\{\left[\mathrm{Nb}_{6} \mathrm{Cl}_{12}\left(\mathrm{H}_{2} \mathrm{O}\right)_{6}\right] @ \mathrm{Y}-\mathrm{CD}\right\}^{2+}$. NMR, ITC and ESI-MS techniques were used to study the interaction between the inorganic cluster and the organic macrocycle in water. Such molecular association affects the biological activity of $\left[\mathrm{Nb}_{6} \mathrm{Cl}_{12}\left(\mathrm{H}_{2} \mathrm{O}\right)_{6}\right]^{2+}$, decreasing its cytotoxicity despite enhanced cellular uptake. The 1:1 stoichiometry is maintained in solution over a large window of composition, but crystallization by slow evaporation in air produces a 1:2 host-guest complex $\left[\mathrm{Nb}_{6} \mathrm{Cl}_{12}\left(\mathrm{H}_{2} \mathrm{O}\right)_{6} @(\mathrm{\gamma}-\mathrm{CD})_{2}\right] \mathrm{Cl}_{2} \cdot 2 \mathrm{H}_{2} \mathrm{O}$ showing a cluster unit encapsulated between two molecules of $\mathrm{Y}$-CD. The 1:2 complex was isolated and characterized by XRD, EA, IR and TGA. Quantum chemical calculations were performed to model host-guest interaction.
\end{abstract}

\section{Introduction}

Specific molecular recognition occurs in a wide range of biological processes playing a key role at different levels of supramolecular interactions. One of the main types of molecular recognition results in formation of host-guest complexes. The most widely studied class of host molecules are cyclodextrins
(CDs), cyclic oligosaccharides consisting of six, seven or eight glucopyranose units, respectively shorthanded as $\alpha-C D, \beta-C D$ and $\mathrm{Y}-\mathrm{CD}$. This ability to form host-guest complexes has led to the use of CDs as material in a number of industries. ${ }^{[1][2]}$ For example, CDs are used in pharmaceutical industry, ${ }^{[3][4][5][6]}$ in analytical applications ${ }^{[7][8][9][10]}$ and in the chemical technology as catalysts or catalyst additives, phase-transfer agents and stabilizer of functional species such as azo dyes. ${ }^{[11][12][13][14]}$

Medicinal use of CDs, focusing on the complexation of problematic drugs, such as poorly soluble, unstable, irritating, or difficult to formulate substances ${ }^{[15]}$ resulted in improved wettability, dissolution, and solubility. Other positive features include improved stability, reduced side effects, and alleviation of undesired properties, e.g., bitter taste or repelling odor. Cyclodextrins can be used practically in any drug forms - oral, rectal, pulmonary, external, ocular, etc. ${ }^{[16][17]}$

There is a variety of important interactions involved in the complexation with CDs. ${ }^{[1][18][19][20][21]}$ Bender with co-workers, as well as Saenger, assume that water molecules captured inside the cavity of $C D$ torus are highly energetic, i.e., enthalpically frustrated: these molecules are unable to undergo the favorable four-fold hydrogen bindings characteristic in bulk water. ${ }^{[22][23][24]}$ This concept of enthalpically frustrated water molecules has found support in recent theoretical studies, which also revealed 
the role of the concave geometry of the apolar binding pocket with respect to the nature and shape of the guest. ${ }^{[25][26][27][28][29]}$ Evaluation of metal-cluster complexes, including $\mathrm{M}_{6}$-based clusters in terms of anticancer therapy is one of the promising areas of research. Currently, luminescent octahedral molybdenum, tungsten, or rhenium clusters are actively studied as promising photosensitizers for photodynamic therapy. ${ }^{[30][31][32]}$ On the other hand, Echeverría with co-workers recently demonstrated selective cytotoxicity of the $\mathrm{Re}_{6}$-cluster complex $\left[\mathrm{Re}_{6} \mathrm{Se}_{8} \mathrm{I}_{6}\right]^{3-}$ toward different cell lines. ${ }^{[33]}$ They have shown that this cluster induces selective tumor cell death without affecting normal cells, which turns it into promising anticancer and cytostatic agent. The authors explain this behavior by the ability of $\left[\mathrm{Re}_{6} \mathrm{Se}_{8} \mathrm{I}_{6}\right]^{3-}$ to penetrate through the cell membrane until ssDNA bonding in the nucleus.

Recently we have discovered the formation of a new type of host-guest supramolecular complexes based on the specific recognition between $\mathrm{Y}-\mathrm{CD}$ and cationic $\left[\mathrm{Ta}_{6} \mathrm{Br}_{12}\left(\mathrm{H}_{2} \mathrm{O}\right)_{6}\right]^{2+}$ cluster, used in the design of soft nanomaterials. ${ }^{[34]}$ The key role in the step-by-step formation of such kind of assemblies lies in the specific recognition of building units at the molecular level supported by solvent effect arising from chaotropic behavior of the cluster ion (water structure breaking). Moreover, formation of the host-guest complexes based on anionic octahedral rhenium chalcogenide clusters $\left[\operatorname{Re}_{6} Q_{8}(C N)_{6}\right]^{4-}(Q=S$, Se, Te $)$ has been demonstrated. ${ }^{[35][36]}$ Hence occurrence of such adducts shows the ability of the $C D$ to form energetically stable supramolecular complexes with both cationic or anionic clusters.

In this research we focus on the complexation behavior and biological activity of hexanuclear niobium complex $\left[\mathrm{Nb}_{6} \mathrm{Cl}_{12}\left(\mathrm{H}_{2} \mathrm{O}\right)_{6}\right]^{2+}$ in the presence of $\mathrm{y}-\mathrm{CD}$. Herein we report the synthesis and crystal structure of a new host-guest compound $\left\{\left[\mathrm{Nb}_{6} \mathrm{Cl}_{12}\left(\mathrm{H}_{2} \mathrm{O}\right)_{6}\right] @(\mathrm{\gamma}-\mathrm{CD})_{2}\right\} \mathrm{Cl}_{2}$. Since the biological properties of group 5 hexanuclear clusters $\left\{\mathrm{M}_{6} \mathrm{X}_{12}\right\}^{\mathrm{n}+}(\mathrm{M}=\mathrm{Nb}, \mathrm{Ta} ; \mathrm{X}=\mathrm{Cl}, \mathrm{Br}$, I) have never been studied, we evaluated the cytotoxicity, genotoxicity, cellular uptake and localization of free hexaniobium cluster complex $\left[\mathrm{Nb}_{6} \mathrm{Cl}_{12}\left(\mathrm{H}_{2} \mathrm{O}\right)_{6}\right] \mathrm{Cl}_{2}$ and influence of $\mathrm{y}-\mathrm{CD}$ acting as a properties tuning agent e.g. changes in cytotoxicity, penetration or intracellular localization, on larynx carcinoma (Hep-2) and normal fibroblastic (DK-4) cell lines. Additionally, we demonstrated overproducing of reactive oxygen species (ROS) in cells that contributes to the cluster cytotoxicity.

\section{Results and Discussion}

\section{Synthesis and structure}

Starting $\mathrm{Nb}_{6} \mathrm{Cl}_{14} \cdot 6 \mathrm{H}_{2} \mathrm{O}$ material is a brown solid synthesized from $\mathrm{NbCl}_{5}{ }^{[37]}$ which solubilizes slowly after reflux producing green aqueous solutions of a $\left[\mathrm{Nb}_{6} \mathrm{Cl}_{12}\left(\mathrm{H}_{2} \mathrm{O}\right)_{6}\right]^{2+}$ aqua complex (1). Typically, after dissolution a small amount of insoluble materials remains. Due to this fact we determined the effective concentration of niobium cluster solution using thermogravimetry technique to calculate correct molar absorption coefficients $\varepsilon$ (Fig. S1). Aqueous solutions of $\left[\mathrm{Nb}_{6} \mathrm{Cl}_{12}\left(\mathrm{H}_{2} \mathrm{O}\right)_{6}\right]^{2+}$ are air stable and were used for further investigations as stock solutions. Addition of two or more equivalents of $\mathrm{Y}-\mathrm{CD}$ to hot solution leads to the formation of green cubic crystals of $\left\{\left[\mathrm{Nb}_{6} \mathrm{Cl}_{12}\left(\mathrm{H}_{2} \mathrm{O}\right)_{6}\right] @(\gamma-\right.$ $\left.\mathrm{CD})_{2}\right\} \mathrm{Cl}_{2} \cdot 2 \mathrm{H}_{2} \mathrm{O}(2)$ upon cooling.

The complex crystallizes in a tetragonal (1422) space group (Table S1). The main building block of the crystal structure is the supramolecular cation $\left\{\left[\mathrm{Nb}_{6} \mathrm{Cl}_{12}\left(\mathrm{H}_{2} \mathrm{O}\right)_{6}\right] @(\mathrm{\gamma}-\mathrm{CD})_{2}\right\}^{2+}$ (see Fig. 1), in which the hexanuclear $\left[\mathrm{Nb}_{6} \mathrm{Cl}_{12}\left(\mathrm{H}_{2} \mathrm{O}\right)_{6}\right]^{2+}$ cation appears encapsulated closely by two $\mathrm{Y}-\mathrm{CD}$ molecules. Supramolecular complex 2 is isostructural to the previously characterized $\left\{\left[\mathrm{Ta}_{6} \mathrm{Br}_{12}\left(\mathrm{H}_{2} \mathrm{O}\right)_{6}\right] @(\mathrm{\gamma}-\mathrm{CD})_{2}\right\} \mathrm{Br}_{2} \cdot 14 \mathrm{H}_{2} \mathrm{O} .^{[34]}$

This cationic association can be classified as a host-guest complex, when the cluster unit is a cationic guest inside the cage formed by two $\mathrm{y}-\mathrm{CD}$ host molecules. The subunits are linked together through hydrogen bonding. The four coordinated water molecules in the belt part of the cluster participate in the formation of hydrogen bonds with both host molecules, giving $0 \cdots O$ distances within $2.75-3.30 \AA$ intervals (Figure 1b). Hydrogen bonding are shown also between primary faces of two host molecules involving the $\mathrm{CH}_{2} \mathrm{OH}$ groups through shorter $0 \cdots O$ distances of $2.70-2.90 \AA$. Furthermore, inner chloroligands are involved in hydrogen bond interactions with inwarddirected protons $\mathrm{H} 3$ of $\mathrm{CD}$ with $\mathrm{Cl} \bullet \cdot \mathrm{H}$ distances of $3.15-3.20$ $\AA$. Such bonds are much longer than those observed with Tacluster $(2.83 \AA)$ indicating weaker host-guest connection. a)

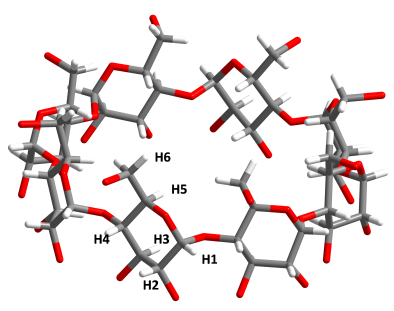

b)

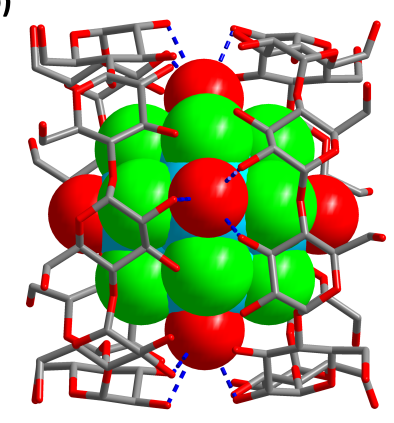

Figure 1. Structures of a) $\mathrm{y}-\mathrm{CD}$ showing the six types of protons in the glucopyranose unit, and b) the inclusion complex $\left\{\left[\mathrm{Nb}_{6} \mathrm{Cl}_{12}\left(\mathrm{H}_{2} \mathrm{O}\right)_{6}\right] @(\mathrm{\gamma}-\mathrm{CD})_{2}\right\}^{2+}$. Blue dashed lines indicate hydrogen bonds between water ligands and $\mathrm{OH}$ groups of $\mathrm{Y}-\mathrm{CD}$.

In the crystal structure the supramolecular cations form dimeric tubular structures in [001] crystal direction (Fig. S2 and S3), which can be classified as secondary building blocks (SBB). Due to high positional disordering of $\mathrm{Cl}^{-}$counter anions and crystallization water molecules in the structure, the $\mathrm{Cl}^{-}$positions cannot be precisely localized. Considering that $\left\{\mathrm{Ta}_{6} \mathrm{Br}_{12}\right\}$ - and $\left\{\mathrm{Nb}_{6} \mathrm{Cl}_{12}\right\}$-cluster derivatives are isostructural, the $\mathrm{Cl}^{-}$anions have been then located in the positions occupied by the $\mathrm{Br}^{-}$ions in the analog structure. We thus assume localization of anions inside the dimeric tubular SBB, ensuring contacts through $\mathrm{H} \bullet \bullet \mathrm{Cl}$ interactions. Besides, dimeric tubular associates form a $b c c$ sub-lattice with SBB forming infinite columns running along [001] crystallographic direction.

\section{Solution studies}

Compound $\mathbf{2}$ was studied in solution by means of Isothermal Titration Calorimetry (ITC), mass spectrometry and nuclear magnetic resonance (NMR) spectroscopy. The interaction between $\mathrm{Y}-\mathrm{CD}$ and the cationic cluster $\left[\mathrm{Nb}_{6} \mathrm{Cl}_{12}\left(\mathrm{H}_{2} \mathrm{O}\right)_{6}\right]^{2+}$ was probed by ${ }^{1} \mathrm{H}$ NMR titration experiment. Upon increasing the amount of the cationic cluster in $\mathrm{D}_{2} \mathrm{O}$ solution of $1 \mathrm{mM} \mathrm{Y}$-CD (Fig. 2), ${ }^{1} \mathrm{H}$ NMR spectra showed significant line broadening of all signals together with slight chemical shift changes of some specific resonances. Surprisingly, the most affected signals were 
those corresponding to the outer peripheral $\mathrm{H} 1$ and $\mathrm{H} 4$ protons of the CD tori $(\Delta \delta \approx-0.08 \mathrm{ppm})$ (Fig. S4), while among the inward directed protons, $\mathrm{H} 3$ appears the most altered by $\Delta \delta \approx-$ $0.02 \mathrm{ppm})$. Such unexpected observations suggest that the cationic cluster is able to interact with both the external or inner wall of the $\gamma$-CD. Otherwise, the $C D$ macrocycle could also undergo conformational distortion able to alter mostly the external $\mathrm{C}-\mathrm{H}$ bonds. In all cases, this NMR fingerprint is drastically different to that previously observed with the strong inclusion complex $\left\{\left[\mathrm{Ta}_{6} \mathrm{Br}_{12}\left(\mathrm{H}_{2} \mathrm{O}\right)_{6} @(\mathrm{\gamma}-\mathrm{CD})_{2}\right]\right\}^{2+}$. Indeed, the NMR analysis was fully consistent with the retention of the 2:1 supramolecular adduct in aqueous solution, ${ }^{[34]}$ where the most affected resonance corresponded to the signal attributed to the inward-directed $\mathrm{H} 3$ protons. Furthermore, NMR study evidenced a frozen inclusion complex arising from a slow host-guest exchange. In the current case of the $\left\{\mathrm{Nb}_{6} \mathrm{Cl}_{12}\right\}$-based cluster, the $\mathrm{H} 3$ signal exhibited only tiny change for large excess of cluster, indicating a moderate complexation in solution. Consistently, Job plots (Fig. S5) indicate 1:1 CD:cluster stoichiometry as prominent species.
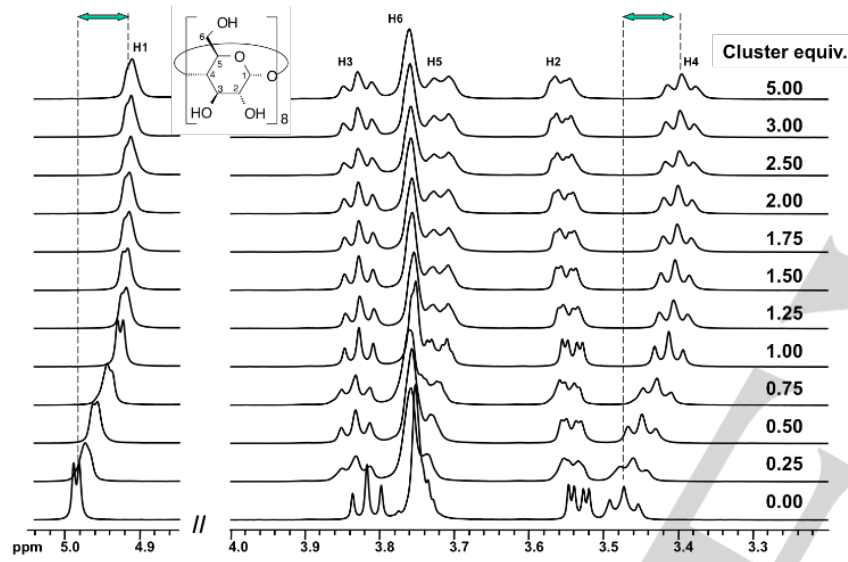

Figure 2. ${ }^{1} \mathrm{H}$ NMR spectra of $1 \mathrm{mM} y-C D$ in the presence increasing amount of $\left[\mathrm{Nb}_{6} \mathrm{Cl}_{12}\left(\mathrm{H}_{2} \mathrm{O}\right)_{6}\right]^{2+}$ cluster.

Stability of 2 in aqueous solution has been studied with ESI-MS technique. The ESI-MS of the 2:1 complex aqueous solution consists in a set of species including 2:1 and 1:1 adducts as well as free species, observed as desolvated $\left[\mathrm{Nb}_{6} \mathrm{Cl}_{12}\right]^{2+}$ species (Fig. S6). This result appears in fair agreement with quantumchemical calculations which showed favorable association for only 1:1 complex in aqueous solution (see below).

ITC (Table S2 and Fig. S7) allows quantification of interactions between the $\gamma-\mathrm{CD}$ and $\left[\mathrm{Nb}_{6} \mathrm{Cl}_{12}\left(\mathrm{H}_{2} \mathrm{O}\right)_{6}\right]^{2+}$ by measuring binding constants, enthalpy $\Delta_{\mathrm{r}} H^{*}$ and entropy $\Delta_{\mathrm{r}} S^{*}$ changes, which are summarized in Table 1 and compared to previously obtained data with $\left[\mathrm{Ta}_{6} \mathrm{Br}_{12}\left(\mathrm{H}_{2} \mathrm{O}\right)_{6}\right]^{2+}$. ${ }^{[3]}$ While the ITC data of $\left[\mathrm{Ta}_{6} \mathrm{Br}_{12}\left(\mathrm{H}_{2} \mathrm{O}\right)_{6}\right]^{2+} / \gamma$-CD system were analyzed using a two-site binding model involved in a sequential process, those of $\left[\mathrm{Nb}_{6} \mathrm{Cl}_{12}\left(\mathrm{H}_{2} \mathrm{O}\right)_{6}\right]^{2+}$ are rather consistent with a $1: 1$ stoichiometry model. This means that recognition processes are significantly dependent on the nature of the cluster, where the aggregation process leads consecutively to the $1: 1$ and the $2: 1$ adducts with $\left\{\mathrm{Ta}_{6} \mathrm{Br}_{12}\right\}$-based cluster and restricted to the 1:1 stoichiometry with the $\left\{\mathrm{Nb}_{6} \mathrm{Cl}_{12}\right\}$ cluster. Consistently, the ITC results confirm the difference in host-guest association affinity with a $K_{11}$ decrease of two magnitude orders from $\left\{\mathrm{Ta}_{6} \mathrm{Br}_{12}\right\}$ cluster to $\mathrm{Nb}$ type-cluster. Furthermore, large association constants found in both cases result of enthalpy driven processes, each compensated more or less by entropy penalty. Such thermodynamic fingerprints featured by a large enthalpy gains counterbalanced by the strong entropic energy appear characteristic for supramolecular assembly involving super chaotrope species which release high energy water molecules upon the recognition process. ${ }^{[38]}$ Overall results are rather consistent with weak interactions between $\left[\mathrm{Nb}_{6} \mathrm{Br}_{12}\left(\mathrm{H}_{2} \mathrm{O}\right)_{6}\right]^{2+}$ and $\gamma-C D$ in solution as shown by ${ }^{1} \mathrm{H}$ NMR in comparison to the analogous $\left[\mathrm{Ta}_{6} \mathrm{Br}_{12}\left(\mathrm{H}_{2} \mathrm{O}\right)_{6}\right]^{2+} / \gamma-\mathrm{CD}$ system. This difference in behavior can be explained on the basis of size-matching effect. Calculated cluster volumes give 407 and $460 \AA^{3}$ for $\left\{\mathrm{Nb}_{6} \mathrm{Cl}_{12}\right\}$ and $\left\{\mathrm{Ta}_{6} \mathrm{Br}_{12}\right\}$ clusters, correspondingly. Such a difference appears significant enough to explain the solution behavior as a similar correlation were previously established for rhenium clusters $\left\{\operatorname{Re}_{6} Q_{8}\right\}$ with $Q=S$, Se or Te. ${ }^{[35][36]}$ On the other hand, large negative values of both $\Delta_{r} H^{*}$ and $T \Delta_{r} S^{*}$ parameters should be also related to the nature of the supramolecular adducts arising from dynamic interactions between the $\left\{\mathrm{Nb}_{6} \mathrm{Cl}_{12}\right\}$-cluster and the external / internal part of the $\gamma$-CD rather than the typical $1: 1$ and $1: 2$ host-guest species observed in the case of the $\left\{\mathrm{Ta}_{6} \mathrm{Br}_{12}\right\}$-based cluster.

Table 1. Binding constants $K$ involving $\left\{\mathrm{Nb}_{6} \mathrm{Cl}_{12}\right\}$ - and $\left\{\mathrm{Ta}_{6} \mathrm{Br}_{12}\right\}$-based octahedral cluster cations with $\gamma-\mathrm{CD}$ and associated thermodynamic parameters (in kJ. $\mathrm{mol}^{-1}$ ) at $T=298 \mathrm{~K}$.

\begin{tabular}{llllll}
\hline Guest & Guest:CD & $K\left(M^{-1}\right)$ & $\Delta_{\mathrm{r}} H^{*}$ & $\mathrm{~T} \Delta_{\mathrm{r}} \mathrm{S}^{*}$ & $\Delta_{\mathrm{r}} \mathrm{G}^{*}$ \\
\hline$\left[\mathrm{Nb}_{6} \mathrm{Cl}_{12}\left(\mathrm{OH}_{2}\right)_{6}\right]^{2+}$ & $1: 1$ & $2.2 \times 10^{3}$ & -40.5 & -21.4 & -19.1 \\
{$\left[\mathrm{Ta}_{6} \mathrm{Br}_{12}\left(\mathrm{OH}_{2}\right)_{6}\right]^{2+\mathrm{a}}$} & $1: 1$ & $1.5 \times 10^{5}$ & -34.2 & -5.0 & -29.4 \\
& $1: 2$ & $1.3 \times 10^{5}$ & -21.4 & 8.0 & -29.4 \\
\hline
\end{tabular}

[a] data from reference [33].

\section{Quantum-chemical calculations}

The differences in Gibbs' free energy at $T=298.15 \mathrm{~K}$ and $p=1$ atm were computed for the following five equilibria:

$$
\begin{aligned}
& \mathrm{\gamma}-\mathrm{CD}+40 \mathrm{H}_{2} \mathrm{O}=(\mathrm{\gamma}-\mathrm{CD}) \cdot\left(\mathrm{H}_{2} \mathrm{O}\right)_{40} \\
& (\mathrm{\gamma}-\mathrm{CD})_{2}+48 \mathrm{H}_{2} \mathrm{O}=(\mathrm{\gamma}-\mathrm{CD})_{2} \cdot\left(\mathrm{H}_{2} \mathrm{O}\right)_{48} \\
& 2 \mathrm{\gamma}-\mathrm{CD}=(\mathrm{\gamma}-\mathrm{CD})_{2}
\end{aligned}
$$

Processes (A1) and (A2) describe solvation of $\mathrm{\gamma}-\mathrm{CD}$ and $(\mathrm{\gamma}-\mathrm{CD})_{2}$, respectively.For eq. (B), the head-to-head dimerization mode of $\mathrm{Y}-\mathrm{CD}$ is chosen, since it was shown to be preferred with respect to other aggregation types. ${ }^{[39]}$ Processes (C1) and (C2) describe inclusion of the $\left\{\mathrm{Nb}_{6} \mathrm{Cl}_{12}\right\}$-cluster inside the torus of $\mathrm{Y}-\mathrm{CD}$ and $(\mathrm{\gamma}-$ $C D)_{2}$, respectively. The results obtained both in the gas phase and aqueous solution are summarized in Table 2. 
Table 2. Differences in Gibbs' free energy, $\Delta G$, at $T=298.15 \mathrm{~K}$ and $p=1 \mathrm{~atm}$, computed at DFT M06-2X level (basis set specified in the Computational Details). Data are listed in units of $\mathrm{kJ} / \mathrm{mol}$.

\begin{tabular}{lll}
\hline & \multicolumn{1}{l}{ gas } & Water \\
\hline A1 & \multicolumn{1}{l}{} & 965.2 \\
A2 & - & 1156.9 \\
B & 381.2 & 378.6 \\
C1 & 207.8 & 291.4 \\
C2 & 255.9 & 275.4 \\
\hline
\end{tabular}

As shown in Table 2, dimerization of $\mathrm{Y}-\mathrm{CD}$ according to process (B) seems to be energetically more favorable in the gas phase than in aqueous solution. Such a scenario appears quite reasonable since the stabilization is mainly due to hydrogen bonding. In the dimer, the two $\mathrm{Y}-\mathrm{CD}$ units interact mutually through 16 hydrogen bonds. From values given in Table 2, the average contribution per $\mathrm{H}$-bond can be roughly estimated to about $\Delta G / n \sim 23.8 \mathrm{~kJ} / \mathrm{mol}$, which is in reasonable agreement with the typical mean value of $\mathrm{O}-\mathrm{H} \cdots: \mathrm{O}$ strength $(\sim 21 \mathrm{~kJ} / \mathrm{mol})$. In aqueous solution, solvation of either the monomeric or the dimeric $\gamma$-CD species is evidenced as a highly favorable process (see reactions $\mathrm{A} 1$ and $\mathrm{A} 2$ ).

Regarding the inclusion process of the $\left\{\mathrm{Nb}_{6} \mathrm{Cl}_{12}\right\}$-based cluster inside the $y-C D$ torus, formation of the $1: 1$ adduct (equation $C 1$ ) reveals to be the most stable species in aqueous solution $(\Delta G=$ $-291 \mathrm{~kJ}^{\mathrm{mol}}{ }^{-1}$ ) compared to the other scenario depicted in Table 2. This supports the experimental evidences that the 1:1 adduct corresponds to the predominant species in aqueous solution. Furthermore, additional evidences are provided by computed ${ }^{1} \mathrm{H}$ NMR shifts. Considering the isolated $Y-C D$ and $(Y-C D)_{2}$, and the related adducts $\left\{\left[\mathrm{Nb}_{6} \mathrm{Cl}_{12}\left(\mathrm{H}_{2} \mathrm{O}\right)_{6}\right] @(\mathrm{\gamma}-\mathrm{CD})\right\}^{2+}$ and $\left\{\left[\mathrm{Nb}_{6} \mathrm{Cl}_{12}\left(\mathrm{H}_{2} \mathrm{O}\right)_{6}\right] @(\mathrm{\gamma}-\mathrm{CD})_{2}\right\}^{2+}$, computation results predict a shift for the signals of $\mathrm{H} 1$ and $\mathrm{H} 4$ protons of $\mathrm{CD}$. In the case of $1: 1$ adduct, a quite good agreement was found between calculated and experimental shifts. Variations are about $-0.074 \mathrm{ppm}$ for both $\mathrm{H} 1$ and $\mathrm{H} 4$.

To investigate the presence and nature of possible interactions, the non-covalent interaction $(\mathrm{NCl})$ index combined with the second derivative of the reduced density gradient (RDG) along the second main axis of variation were employed. RDG analysis (Fig. S8) of ground state optimized geometry of $\left\{\left[\mathrm{Nb}_{6} \mathrm{Cl}_{12}\left(\mathrm{H}_{2} \mathrm{O}\right)_{6}\right] @(\mathrm{\gamma}-\mathrm{CD})\right\}^{2+}$ shows the presence of several noncovalent interaction regions (see panel (a)). In particular, chlorine atoms in the equatorial plane can interact with $y-C D$ via $\mathrm{Cl} \bullet \cdot \mathrm{H}$ (panel (b)) or $\mathrm{Cl} \bullet \cdot \mathrm{O}$ interactions (panel (c)), both of them having attractive character.

To summarize, solution studies and quantum-chemical calculations suggest several types of supramolecular assemblies based on 1:1 stoichiometry resulting of either hostguest complex or "outer complexes" built from external interactions. Such a scenario is schematically depicted in Figure 3 , where the "outer" $1: 1$ adduct resulting from $\gamma$-CD $\bullet \bullet$ cluster lateral interactions can be proposed as the simplest model while more complicated aggregates could be envisioned.

\section{Biological properties}

The initial stage in the evaluation of the biological properties of new compounds is the determination of their cytotoxicity. This

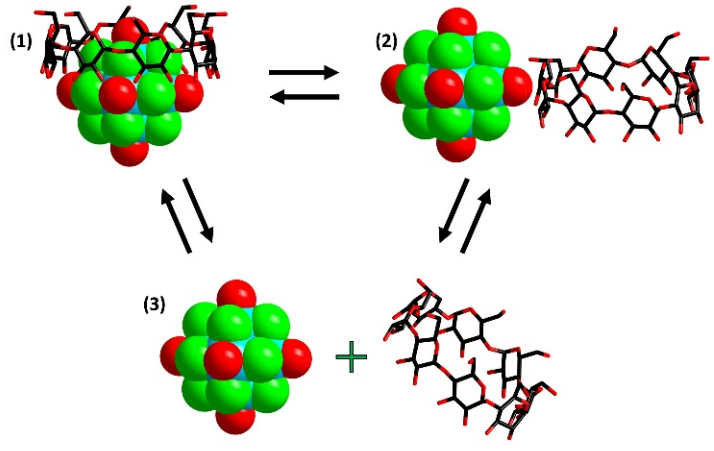

Figure 3. Schematic representation of equilibrated species in the aqueous solution containing $\gamma-\mathrm{CD}$ and $\left[\mathrm{Nb}_{6} \mathrm{Cl}_{12}\left(\mathrm{H}_{2} \mathrm{O}\right)_{6}\right]^{2+}$ cationic cluster.

parameter plays crucial role in understanding the effect of $C D$ molecules on biological properties of the clusters. In order to evaluate the influence of $\mathrm{Y}-\mathrm{CD}$ on cytotoxicity of $\left[\mathrm{Nb}_{6} \mathrm{Cl}_{12}\left(\mathrm{H}_{2} \mathrm{O}\right)_{6}\right]^{2+}$ the MTT colorimetric assay on cancer Hep-2 and normal DK-4 cell lines was used. It is important to note that, hereinafter, studies of compound $\mathbf{2}$ in fact reflect mainly the influence of the 1:1 form on cell viability, because, as shown earlier previously, this form corresponds to the prominent species mainly oxists in aqueous solution. According to the data given in Fig. 4, the half maximal inhibitory concentration $\left(\mathrm{IC}_{50}\right)$ for cluster complex 1 after $72 \mathrm{~h}$ of incubation $(74 \pm 7 \mu \mathrm{M}$ for Hep2 and $594 \pm 24 \mu \mathrm{M}$ for DK-4) were lower than those for the adduct with $\gamma-C D(2)(222 \pm 20 \mu \mathrm{M}$ for Hep-2, $953 \pm 86 \mu \mathrm{M}$ for DK-4). At the same time, the cytotoxicity of both compounds is higher for cancer Hep-2 cells than for normal DK-4. It is important to note, that the cytotoxic evaluation experiments were carried out at the micromolar concentration range of the cluster and $C D$. Since the binding constant of the $1: 1$ adduct is $1.3 \times 10^{3}$ $\mathrm{M}^{-1}$ (at $308 \mathrm{~K}$ ), its presence in the experimental medium drastically depends on the concentrations used at this range. The calculated content in the 1:1 adduct from dissolution of $\mathbf{2}$ in the experimental medium is presented on the Figure 4 as a gray curve with asterisks. As it can be seen from the data the differences in the MTT curve pattern for Hep-2 cells appear at the concentration $25.31 \mu \mathrm{M}$ that corresponds to an about $6 \%$ content of $1: 1$ adduct in solution. Subsequent increase in

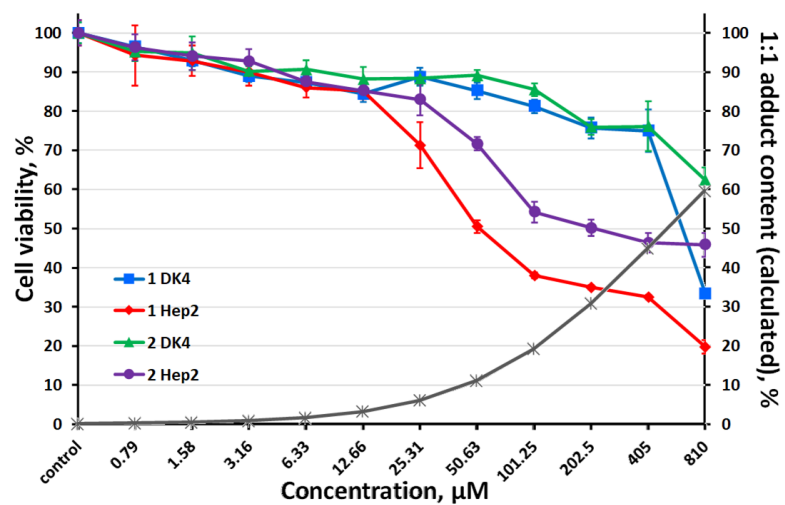

concentration of the complexes leads to the greater difference in 
Figure 4. Effect of 1 and 2 on viability of DK-4 (blue and green lines) and Hep2 (red and violet lines) cells measured by MTT. Gray line indicates calculated $1: 1$ adduct content (\%) in solution at $308 \mathrm{~K}$ according to ITC data.

their cytotoxicity. The significant difference in the cytotoxicity of 1 and 2 for DK- 4 cells was observed only at the concentrations when the $1: 1$ adduct content exceeds $50 \%$ These findings suggest that i) the $C D$ adduct (when appears) has lower cytotoxicity due to the shielding effect of $\mathrm{Y}-\mathrm{CD}$ and ii) both free and encapsulated clusters have selective cytotoxic effect for tumor cells in comparison with normal cells. A possible reason for such behavior can be the difference in the cellular uptake of 1 and 2 by Hep- 2 and DK- 4 cells. Unlike previously investigated octahedral cluster complexes in biological systems ${ }^{[40][41][42][43]}$ the hexaniobium cluster complexes do not exhibit luminescence, making their cellular uptake unavailable for studies by fluorescent microscopy or flow cytometry. However, we were able to quantify the accumulation of $\mathbf{1}$ in Hep-2 and DK-4 cells by inductively coupled plasma mass spectrometry (ICP-MS). The results obtained show that the cluster $\left[\mathrm{Nb}_{6} \mathrm{Cl}_{12}\left(\mathrm{H}_{2} \mathrm{O}\right)_{6}\right] \mathrm{Cl}_{2}$ is able to penetrate through cell membrane and amounts of niobium atoms accumulated by cells of both lines are actually relatively similar (Table S3). Note, that the presence of CD in the case of 2 at investigated concentration $(1.5 \mu \mathrm{M})$ does not influence on its cellular uptake (Table S2). Moreover, it is most likely that after cellular uptake, even at high concentration of $\mathbf{2}$, the real content of $1: 1$ adduct inside the cells will be extremely small (if at all).

Therefore, it is clear that the difference in the cytotoxicity between cell cultures is not related to the difference in the cellular uptake of cluster complexes, but in the mechanism of toxicity.

Transmission electron microscopy assay with elemental mapping on Hep-2 cells incubated with $\mathbf{1}$ indicated cellular uptake and subcellular localization of niobium atoms (Fig. S9). According to the TEM images, the cluster is located inside the nucleus and in mitochondria. It is also important to mention that no signs of abnormal changes of cells ultrastructure were observed. This ability to penetrate into the cell nucleus and mitochondria can lead to the binding with DNA molecules. The possibility of interaction between $\left[\mathrm{Re}_{6} \mathrm{Se}_{8} \mathrm{I}_{6}\right]^{3-}$ cluster complex and SsDNA has already been referred. ${ }^{[33]}$

The ability of the cluster to enter the nucleus and mitochondria of Hep-2 cells is an unexpected finding, revealing the potential use of this cluster as a targeting deliverer of various substances, such as cytostatics, in tumor cells. To evaluate the binding of the niobium cluster with DNA, the Hep-2 cells with 1 were incubated and the DNA was then isolated. The niobium quantity determinations in the isolated DNA by ICP-MS clearly demonstrate the presence of $\mathrm{Nb}$ in the samples DNA and correspond to $1.0 \pm 0.3 \mu \mathrm{g}$ per $1 \mathrm{mg}$ of DNA. The $\mathrm{Nb}$ amount in the control DNA (without incubation with cluster compounds) was $0.020 \pm 0.005 \mu \mathrm{g}(\mathrm{Nb}) / \mathrm{mg}(\mathrm{DNA})$. This data allows us to assume that hexaniobium clusters can really bind to DNA in some way.

This binding of the cluster to DNA can lead to DNA damage, and as a result, to replication blocking (genotoxicity). To assess the contribution of genotoxicity into the toxicity of 1 , the SOS chromotest on E. coli strain PQ37 was used. Cluster compound showed slight genotoxic effects (Table S4), indicating some interactions between the clusters and DNA, regardless of the CD presence. Descending trend of I(c) (induction factor, considered as the ratio of the activity of two enzymes, beta-galactosidase to alkaline phosphatase) with increasing complex concentration is due to the cell toxicity of the cluster: with decreasing number of bacteria (decreased activity of alkaline phosphatase) the SOS response weakened. Moreover, the similar genotoxicity of the niobium cluster correlates with the similar quantity of the $\mathrm{Nb}$ in the samples.

Since 1 has slight genotoxicity it does not seem to be a main reason of its cytotoxicity. Moreover, it does not explain the difference in the toxicity of the compounds on different cell lines. One of the common mechanisms for cellular death is overproducing of reactive oxygen species (ROS). In order to monitor the presence of intracellular ROS after incubation with 1 and 2, a cell-permeable fluorescent probe, 5,6-carboxy-2',7'dichlorofluoresceindiacetate (DCFH-DA), sensitive to oxidation by different ROS including singlet oxygen, was used. A $100 \mu \mathrm{M}$ $\mathrm{H}_{2} \mathrm{O}_{2}$ solution was used as a ROS-positive control reference. According to the data obtained (Fig. S10, S11) incubation both with $\mathbf{1}$ and $\mathbf{2}$ increased the ROS level in the cells.

In general, the ROS level was higher for compound $\mathbf{1}$ than for $\mathbf{2}$ in both cell cultures. Indeed, the presence of cyclic oligosaccharide $Y-C D$ can inhibit oxidative stress caused by cluster complex. ${ }^{[4]}$ Nevertheless, both compounds show a tendency to generate ROS in Hep-2 cancer cells more efficiently. These results may explain the difference in the toxicity of 1 and 2 on Hep-2 and DK-4 cells, and indicate contribution of ROS production to the cluster cytotoxicity.

\section{Conclusion}

The specific molecular recognition between $\left[\mathrm{Nb}_{6} \mathrm{Cl}_{12}\left(\mathrm{H}_{2} \mathrm{O}\right)_{6}\right]^{2+}$ and $\mathrm{Y}-\mathrm{CD}$ has been demonstrated. According to the NMR and ITC data, 1:1 complex is preferable in solution, while in solid state 2:1 complex formation was obtained. Dissolution of 2:1 complex crystals leads to formation of an equilibria set including mainly the $1: 1$ adduct and free $\left[\mathrm{Nb}_{6} \mathrm{Cl}_{12}\left(\mathrm{H}_{2} \mathrm{O}\right)_{6}\right]^{2+}$ species.

The first quantum-chemical calculations of octahedral cluster/CD assemblies have been performed. Calculated data appeared rather consistent with the formation of host-guest assemblies both in the gas phase and in aqueous solution. Especially, comparison of the computed values of $\Delta G$ for the $1: 1$ and $2: 1$ complexes gives more negative value for the $1: 1$ complex in aqueous solution which supports the experimental evidences for the presence of 1:1 adduct as dominant form in solution.

Host-guest complex formation between $\left[\mathrm{Nb}_{6} \mathrm{Cl}_{12}\left(\mathrm{H}_{2} \mathrm{O}\right)_{6}\right]^{2+}$ and $\mathrm{Y}-$ $\mathrm{CD}$ changes biological properties of the cluster. In addition to significant differences in cytotoxicity, we observed distinction in the producing of reactive oxygen species, as well as revealed selective toxicity of $\mathbf{1}$ and $\mathbf{2}$ for the Hep-2 tumor cell line. Another interesting result was the ability of hexaniobium cluster to accumulate in the nucleus of tumor cells. According to the experimental data, one can suggest $\left[\mathrm{Nb}_{6} \mathrm{Cl}_{12}\left(\mathrm{H}_{2} \mathrm{O}\right)_{6}\right]^{2+}$ cluster to be useful for the development of novel metal-based anticancer drugs. In context, cyclodextrin plays the role of protective nanocontainer decreasing cytotoxic effect of the clusters allowing possible release inside the cancer cells.

\section{Acknowledgements}


This research was applied in France-Russia international collaboration (IRP-CLUSPOM CNRS). This work was supported by the Russian Science Foundation (grant No. 15-15-10006). Tatiana N. Pozmogova are grateful to the Russian Foundation for Basic Research (grant No. 18-315-00235). The NIIC team thanks the Ministry of Science and Education of the Russian Federation. The RICEL team thanks the state task of RICEL branch of the ICG SB RAS № 0324-2019-0046-C-02.

Keywords: niobium $•$ cluster complex $\bullet \mathrm{\gamma}$-cyclodextrin $\bullet$ cytotoxicity $\cdot$ genotoxicity

[1] C. J. Easton, S. F. Lincoln, Modified Cyclodextrins: Scaffolds and Templates for Supramolecular Chemistry, Imperial College Press, 1999.

[2] A. R. Hedges, Chem. Rev. 1998, 98, 2035-2044.

[3] V. J. Stella, R. A. Rajewski, Pharm. Res. 1997, 14, 556-567.

[4] C. Easton, S. Lincoln, Chem. Aust. 1997, 64, 38475.

[5] L. Szente, J. Szejtli, Trends Food Sci. Technol. 2004, 15, 137-142.

[6] J. Folkman, P. B. Weisz, M. M. Joullié, W. W. Li, W. R. Ewing, Science 1989, 243, 1490-3.

[7] W. A. Konig, J. fur Prakt. Chemie/Chemiker-Zeitung 1993, 335, 486-486.

[8] R. Breslow, T. Ward, R. Armstrong, T. Beesley, Science 1982, 218, 532-7.

[9] B. Chankvetadze, G. Endresz, G. Blaschke, Chem. Soc. Rev. 1996, 25, 141.

[10] B. Chankvetadze, Chem. Soc. Rev. 2004, 33, 337

[11] J. Szejtli, T. Osa, Comprehensive Supramolecular Chemistry (Volume 3), Pergamon, 1999.

[12] M. R. Craig, M. G. Hutchings, T. D. W. Claridge, H. L. Anderson, Angew. Chemie Int. Ed. 2001, 40, 1071-1074.

[13] S. Anderson, T. D. W. Claridge, H. L. Anderson, Angew. Chemie Int. Ed. English 1997, 36, 1310-1313.

[14] J. E. H. Buston, J. R. Young, H. L. Anderson, Chem. Commun. 2000, 0, 905-906.

[15] J. Szejtli, Med. Res. Rev. 1994, 14, 353-386.

[16] T. S. Anirudhan, A. S. Nair, S. S. Nair, Int. J. Biol. Macromol. 2016 , 91, 818-827.

[17] K. Rehman, M. Amin, S. Muda, Drug Res. (Stuttg). 2013, 63, 657662.

[18] K. A. Connors, Chem. Rev. 1997, 97, 1325-1357.

[19] M. L. Bender, M. Komiyama, Cyclodextrin Chemistry, Springer Berlin Heidelberg, Berlin, Heidelberg, 1978.

[20] I. Tabushi, Y. Kuroda, Adv. Catal. 1983, 32, 417-466.

[21] D. Prochowicz, A. Kornowicz, J. Lewiński, Chem. Rev. 2017, acs.chemrev.7b00231.

[22] R. L. VanEtten, J. F. Sebastian, G. A. Clowes, M. L. Bender, J. Am. Chem. Soc. 1967, 89, 3242-3253.

[23] W. Saenger, Angew. Chemie Int. Ed. English 1980, 19, 344-362.

[24] T. D. Kühne, R. Z. Khaliullin, Nat. Commun. 2013, 4, 1450.

[25] R. Baron, J. A. McCammon, Annu. Rev. Phys. Chem. 2013, 64, 151-175.

[26] C. Carey, Y.-K. Cheng, P. J. Rossky, Chem. Phys. 2000, 258, 415425.

[27] N. T. Southall, K. A. Dill, J. Phys. Chem. B 2000, 104, 1326-1331.

[28] T. Young, L. Hua, X. Huang, R. Abel, R. Friesner, B. J. Berne, Proteins Struct. Funct. Bioinforma. 2010, 78, NA-NA.
[29] P. Setny, R. Baron, J. A. McCammon, J. Chem. Theory Comput. 2010, 6, 2866-2871.

[30] A. O. Solovieva, Y. A. Vorotnikov, K. E. Trifonova, O. A. Efremova, A. A. Krasilnikova, K. A. Brylev, E. V. Vorontsova, P. A. Avrorov, L. V. Shestopalova, A. F. Poveshchenko, et al., J. Mater. Chem. B 2016, 4, 4839-4846.

[31] E. V. Svezhentseva, A. A. Ivanov, Y. A. Vorotnikov, S. N. Gyrylova, O. G. Kurskaya, M. A. Gulyaeva, A. Y. Alekseev, Y. V. Mironov, M. A. Shestopalov, A. M. Shestopalov, Mater. Today Proc. 2017, 4, 11430-11436.

[32] A. A. Krasilnikova, A. O. Solovieva, A. A. Ivanov, K. E. Trifonova, T. N. Pozmogova, A. R. Tsygankova, A. I. Smolentsev, E. I. Kretov, D. S. Sergeevichev, M. A. Shestopalov, et al., Nanomedicine Nanotechnology, Biol. Med. 2017, 13, 755-763.

[33] C. Echeverría, A. Becerra, F. Nuñez-Villena, A. Muñoz-Castro, J. Stehberg, Z. Zheng, R. Arratia-Perez, F. Simon, R. Ramírez-Tagle, New J. Chem. 2012, 36, 927.

[34] M. A. Moussawi, N. Leclerc-Laronze, S. Floquet, P. A. Abramov, M. N. Sokolov, S. Cordier, A. Ponchel, E. Monflier, H. Bricout, D. Landy, et al., J. Am. Chem. Soc. 2017, 139, 12793-12803.

[35] A. A. Ivanov, C. Falaise, P. A. Abramov, M. A. Shestopalov, K. Kirakci, K. Lang, M. A. Moussawi, M. N. Sokolov, N. G. Naumov, S. Floquet, et al., Chem. - A Eur. J. 2018, 24, 13467-13478.

[36] A. A. Ivanov, C. Falaise, K. Laouer, F. Hache, P. Changenet, Y. V. Mironov, D. Landy, Y. Molard, S. Cordier, M. A. Shestopalov, et al., Inorg. Chem. 2019, 58, 13184-13194.

[37] R. A. Mackay, R. F. Schneider, Inorg. Chem. 1968, 7, 455-459.

[38] K. I. Assaf, M. S. Ural, F. Pan, T. Georgiev, S. Simova, K. Rissanen, D. Gabel, W. M. Nau, Angew. Chemie Int. Ed. 2015, 54, 6852-6856.

[39] C. S. Nascimento, C. P. A. Anconi, H. F. Dos Santos, W. B. De Almeida, J. Phys. Chem. A 2005, 109, 3209-3219.

[40] E. V. Svezhentseva, Y. A. Vorotnikov, A. O. Solovieva, T. N. Pozmogova, I. V. Eltsov, A. A. Ivanov, D. V. Evtushok, S. M. Miroshnichenko, V. V. Yanshole, C. J. Eling, et al., Chem. - A Eur. J. 2018, 24, 17915-17920.

[41] A. A. Ivanov, D. I. Konovalov, T. N. Pozmogova, A. O. Solovieva, A. R. Melnikov, K. A. Brylev, N. V. Kuratieva, V. V. Yanshole, K. Kirakci, K. Lang, et al., Inorg. Chem. Front. 2019, 6, 882-892.

[42] A. O. Solovieva, K. Kirakci, A. A. Ivanov, P. Kubát, T. N. Pozmogova, S. M. Miroshnichenko, E. V. Vorontsova, A. V. Chechushkov, K. E. Trifonova, M. S. Fufaeva, et al., Inorg. Chem. 2017, 56, 13491-13499.

[43] K. Kirakci, P. Kubát, M. Kučeráková, V. Šícha, H. Gbelcová, P Lovecká, P. Grznárová, T. Ruml, K. Lang, Inorganica Chim. Acta 2016, 441, 42-49.

[44] J. Wang, S. Hu, S. Nie, Q. Yu, M. Xie, Oxid. Med. Cell. Longev. 2016, 2016, 1-13 


\section{Entry for the Table of Contents}

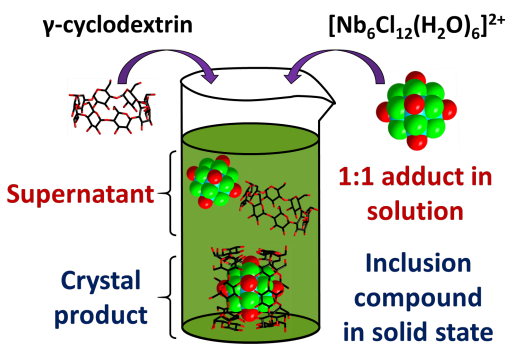

Specific molecular recognition of $\mathrm{y}$-cyclodextrin toward $\left[\mathrm{Nb}_{6} \mathrm{Cl}_{12}\left(\mathrm{H}_{2} \mathrm{O}\right)_{6}\right]^{2+}$ niobium cluster complex in aqueous solutions results in a 1:1 supramolecular assembly $\left\{\left[\mathrm{Nb}_{6} \mathrm{Cl}_{12}\left(\mathrm{H}_{2} \mathrm{O}\right)_{6}\right] @ \mathrm{\gamma}-\mathrm{CD}\right\}^{2+}$. Crystallization results in a 1:2 host-guest complex $\left[\mathrm{Nb}_{6} \mathrm{Cl}_{12}\left(\mathrm{H}_{2} \mathrm{O}\right)_{6} @(\mathrm{\gamma}-\right.$ $\left.\mathrm{CD})_{2}\right] \mathrm{Cl}_{2} \cdot 2 \mathrm{H}_{2} \mathrm{O}$. The molecular association affects the biological activity of $\left[\mathrm{Nb}_{6} \mathrm{Cl}_{12}\left(\mathrm{H}_{2} \mathrm{O}\right)_{6}\right]^{2+}$, decreasing its cytotoxicity despite enhanced cellular uptake. Quantum chemical calculations were performed to model host-guest interaction. 